\title{
No benefit of hydroxychloroquine on SARS-CoV-2 viral load reduction in non-critical hospitalized patients with COVID-19
}

\author{
Klinger Soares Faíco-Filho ${ }^{1}$ (D) Danielle Dias Conte ${ }^{1} \cdot$ Luciano Kleber de Souza Luna $^{1}$. \\ Joseane Mayara Almeida Carvalho ${ }^{1}$. Ana Helena Sitta Perosa ${ }^{2} \cdot$ Nancy Bellei $^{1}$
}

Received: 4 August 2020 / Accepted: 21 October 2020 / Published online: 27 October 2020

(C) Sociedade Brasileira de Microbiologia 2020

\begin{abstract}
Background Some studies have shown that hydroxychloroquine (HCQ) is an effective drug in reducing the in vitro replication of SARS-CoV-2. However, the in vivo effect of HCQ still unclear.

Objectives This study aims to evaluate viral load clearance in patients with COVID-19 who underwent HCQ treatment in comparison with a control group that did not receive the drug.

Study design This prospective study comprised consecutive viral load measurements in patients with COVID-19 hospitalized with a moderate illness. Patients received $400 \mathrm{mg}$ of HCQ every $12 \mathrm{~h}$ for 10 days according to the medical decision. Nasal swab samples were collected from patients during early, intermediary, and final clinical stage of COVID-19.

Results A total of 155 samples were collected from 66 patients with COVID-19 (60\% female), with a median age of 58 years. The viral load between studied groups, assumed as a semiquantitative measure of cycle threshold $(\mathrm{Ct})$ values, presented no significant difference within the three consecutive measures $(\Delta \mathrm{Ct})(p>0.05)$. We also analyzed the $\Delta \mathrm{Ct}$ viral load at different intervals of sample collection ( $\Delta t<7 ; 7-12$; and $>12$ days) without significant differences at any $\Delta \mathrm{Ct}(p>0.05)$.

Conclusion In this study, we did not observe any change in viral load reduction in vivo with the use of HCQ.
\end{abstract}

Keywords Viral load $\cdot$ SARS-CoV-2 $\cdot$ Hydroxychloroquine $\cdot$ COVID-19

\section{Background}

On March 11, 2020, the World Health Organization (WHO) declared the novel severe acute respiratory syndrome coronavirus (SARS-CoV-2), responsible for the coronavirus disease of 2019 (COVID-19), a pandemic, when the virus reached five continents [1]. Since then, several medications have been tested in the treatment of this disease such as hydroxychloroquine (HCQ) [2], tocilizumab [3, 4], remdesivir [5], and heparin [6].

Responsible Editor: Mauricio Nogueira.

Klinger Soares Faíco-Filho

klingerfaiko@hotmail.com

1 Department of Medicine, Discipline of Infectious Diseases, Laboratório de Virologia Clínica, Universidade Federal de São Paulo, Rua Pedro de Toledo, 781 - Vila Clementino, São Paulo, SP 04039-032, Brazil

2 Hospital São Paulo, Universidade Federal de São Paulo, São Paulo, Brazil
Some studies have already demonstrated the broadspectrum antiviral potential of HCQ, a drug widely used as an antimalarial or in the treatment of autoimmune disease [7, 8]. Some studies have demonstrated the in vitro effectiveness of HCQ and chloroquine in controlling the replication of SARS-CoV-2 $[9,10]$.

Other observational study concluded hydroxychloroquine administration was not associated with either a greatly lowered or an increased risk of the composite end point of intubation or death. [11]. The UK RECOVERY trial also concluded that HCQ does not reduce the risk of dying in hospitalized patients [12].

Therefore, more studies need to be carried out to understand the real benefit of HCQ in the treatment of the disease.

\section{Objectives}

The present study aimed to evaluate viral load clearance in patients with COVID-19 who underwent treatment with HCQ in comparison with a control group that did not receive the drug. 


\section{Study design}

\section{Patients and drug administration}

This prospective study comprised consecutive viral load evaluations in patients with COVID-19. A total of 155 samples from 66 hospitalized patients at the University Hospital Sao Paulo, Brazil, aging $>18$ years of age were included in the study. They were diagnosed with the severe acute respiratory syndrome (SARS) due to COVID-19. We excluded patients under 18 years old, ICU patients, and those presenting with severe conditions including malignancy, heart, liver, or renal diseases and severe decompensation (estimated glomerular filtration rate $\leq 30 \mathrm{~mL} / \mathrm{min} / 1.73 \mathrm{~m}^{2}$ ), inadequacy for oral administration, inability to cooperate due to cognitive impairment or poor mental status, pregnancy or lactation, and HCQ allergy.

The HCQ was prescribed according to the medical decision and acceptance of the patient. A dose of $400 \mathrm{mg}$ HCQ was administered orally every $12 \mathrm{~h}$ for 10 days since the admission. The patients were included after approval of the study by the Hospital Research Ethics Committee (CEP n. 4.013.602).

\section{Viral load analysis method}

We used the cycle threshold $(\mathrm{Ct})$ values as a semiquantitative measure of viral load. The amount of viral RNA present in positive samples is inversely proportional to the corresponding $\mathrm{Ct}$ value, meaning that the greater amount of viral RNA, the lower the $\mathrm{Ct}$ value obtained.

To assess the $\mathrm{Ct}$ value variation along time, consecutive RT-PCR tests were conducted in the patients with COVID19, during hospitalization or after discharge, until undetected $\mathrm{Ct}$ values. The variation between consecutive $\mathrm{Ct}$ values for each patient analyzed was evaluated as $\Delta \mathrm{Ct}$.

\section{Samples and RNA preparation}

Nasal swab samples were collected from patients during the early (Ct1), intermediary (Ct2), and final clinical stage of COVID-19 (Ct3) to evaluate the viral clearance.

The RNA of samples was purified using the Quick-RNA Viral Kit (Zymo Research, USA) according to manufacturer instructions. Purified RNA was stored at $-80^{\circ} \mathrm{C}$.

\section{SARS-CoV-2 detection}

Viral detection was performed with AgPath-ID One-Step RTPCR Reagents (ThermoFisher Scientific, Austin, USA), according to manufacture instructions, in a total of $20 \mu \mathrm{L}$ reaction volume, containing $5.0 \mu \mathrm{L}$ of purified RNA, primers and probes ( $400 \mathrm{nM}$ and $200 \mathrm{nM}$, respectively) aiming at the CDC USA protocol N1 and N2 targets of the SARS-CoV-2 nucleoprotein gene, and human ribonuclease $\mathrm{P}$ gene (RNAse $\mathrm{P}$ ) as endogenous control [13]. For the semiquantitative analysis, we used the $\mathrm{Ct}$ values of the more sensitive N2 target. Samples with $\mathrm{Ct}$ values $<40$ were considered positive.

\section{Statistical analysis}

Statistical analysis was performed using Student's $t$ test for parametric data and Mann-Whitney for non-parametric data, with a significance level of $p<0.05$. SPSS 19.0 software and GraphPad 7.0 were used for statistical analysis.

\section{Results}

Among the 66 patients with laboratory-confirmed COVID-19, admitted at the São Paulo Hospital, 60\% (40/66) were male.
Fig. 1 Viral load (Ct values) detected by RT-PCR in the first nasal swabs from patients infected with SARS-CoV-2 $(N=66)$ at hospital admission

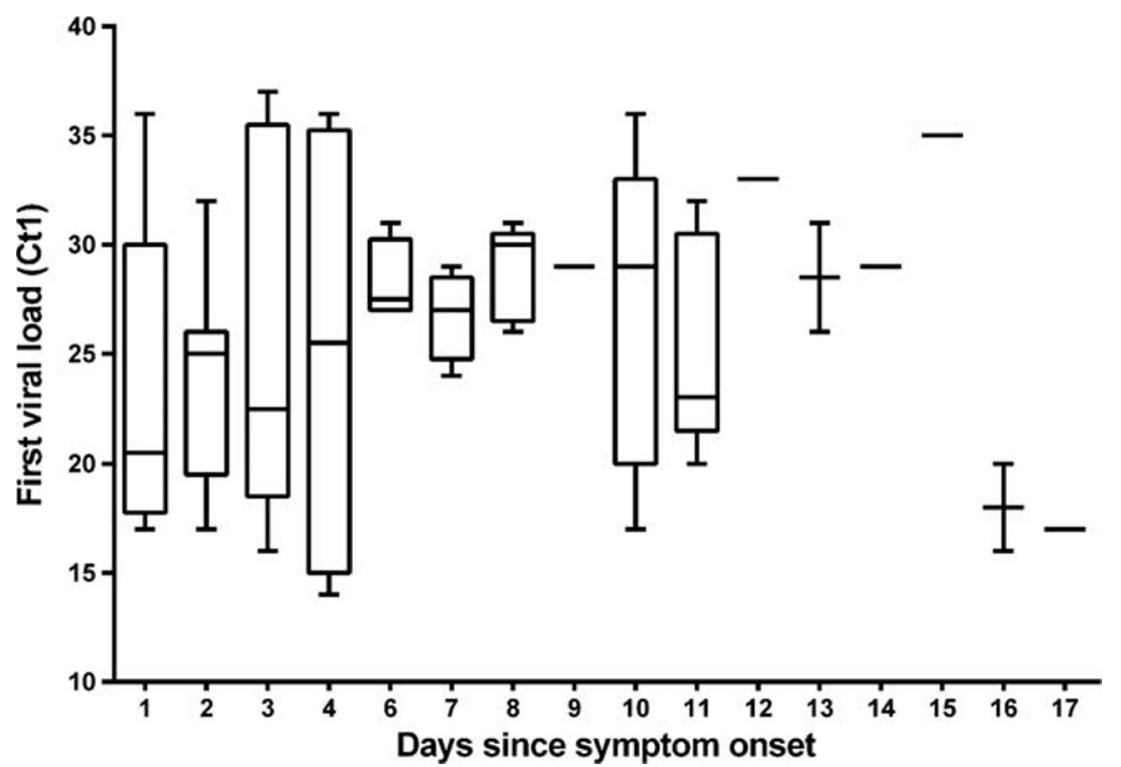


Table 1 Timing of sample collection and RT-PCR $(\mathrm{Ct})$ results

\begin{tabular}{lllll}
\hline Days & $N$ & Average & $\mathrm{SD}^{*}$ & $p$ value \\
\hline $1-7$ & 39 & 25.10 & 6.56 & 0.335 \\
8 or more & 27 & 26.63 & 5.85 & \\
\hline
\end{tabular}

*SD, standard deviation

The median age was 58 (range 18-85) years. The patients presented mild to severe symptoms, radiographic evidence of pneumonia, feverish, or not, and received supplemental oxygen therapy until $5 \mathrm{~L} / \mathrm{min}$, but none was classified as "critical," and none was further admitted to ICU. The majority of patients reported comorbidities such as hypertension $(54.5 \%)$, diabetes mellitus type 2 (36.6\%), and dyslipidemia (28.7\%).

The 155 nasal swabs from the 66 patients were collected from first day symptoms up to the 36th day. We detected the highest viral loads soon after symptom onset, which then gradually decreased towards the detection limit at about the second week. Viral loads were very heterogeneous as shown in Fig. 1.

Patients were analyzed according to the timing of sample collection in relation to illness onset. There was no difference in $\mathrm{Ct}$ values obtained for the first samples of the 66 patients included in the study $(p=0.335)$, demonstrated in Table 1 .

We compared the median viral load $(\mathrm{Ct} 1, \mathrm{Ct} 2$, and $\mathrm{Ct} 3$ values) between the group of patients who underwent HCQ treatment in comparison with a control group that did not receive the drug on the three phases of SARS-CoV-2 infection (early, intermediate, and final). Forty-four patients were negative in the second sample, and only 22 patients' samples were available for $\mathrm{Ct} 3$ value analysis.

For such comparison, Student's $t$ test was used to analyze $\mathrm{Ctl}$ values of first samples at hospital admission, comprising all patients prior to the HCQ administration as an optional drug for treatment. On the other hand, the Mann-Whitney test (for non-parametric data) was used to analyze the $\mathrm{Ct} 2$ and $\mathrm{Ct} 3$

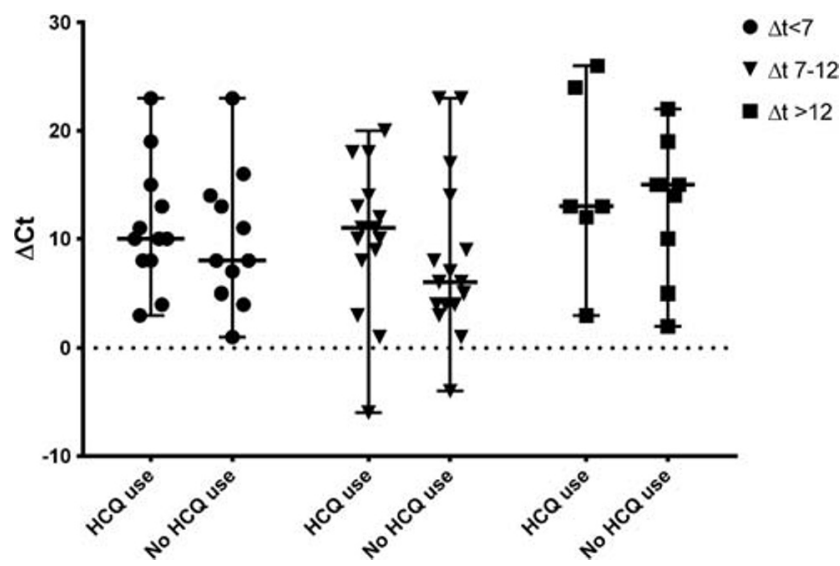

Fig. 2 Upper and lower bars indicate min. and max. $\Delta \mathrm{Ct}$ values. Horizontal bars indicate the median $\Delta \mathrm{Ct}$

value differences between patients that have used HCQ in comparison to the control group (no HCQ use). The data are shown in Table 2.

Next, we compared clearance of viral load $(\Delta \mathrm{Ct}=\mathrm{Ct} 2-\mathrm{Ct} 1$ values) at intervals between the first and second days of samples collection $(\Delta t)$ between the group of patients with use and of HCQ and the group without the use of HCQ. The two groups were analyzed at the three intervals $(<7,7-12$, and $>$ 12 days) established according to observed data from all subjects sampled over time throughout the study. No significant viral load clearance was observed among the groups ( $p=$ 0.362 for $\Delta t<7$ days, 0.403 for $\Delta t 7-12$ days, and 0.516 for $\Delta t>12$ days, two-way ANOVA test). The data are shown in Fig. 2.

\section{Discussion}

The hypothesis that HCQ could be effective is still open. Although the study with a greater number of patients did not
Table $2 \mathrm{Ct}$ values over time according to hydroxychloroquine therapy

\begin{tabular}{llllll}
\hline RT-qPCR & Number & Median Ct & IQR* & $p$ value & Sample collection (days)** \\
\hline Ct1 & & & & \\
HCQ use & 34 & 26.5 & 9 & 0.947 & 3 \\
No HCQ use & 32 & 25.5 & 12 & & 7 \\
Ct2 & & & & \\
HCQ use & 34 & 40 & 4 & 0.197 & 10 \\
No HCQ use & 32 & 40 & 8 & & 14 \\
Ct3 & 13 & 40 & 4 & 0.393 & 17 \\
HCQ use & 90 & 0 & & 22 \\
No HCQ use & 9 & & & \\
RT-qPCR, real-time quantitative RT-PCR & \\
*Interquartile range &
\end{tabular}


show differences in outcome [2], the theme remains under discussion even though the fact that their effect on viral replication is not well understood.

We establish a study to assess viral clearance in patients without a severe outcome so that we could compare patients more homogeneously. The viral load is an established method used for the evaluation of therapies and was a biomarker in the study of lopinavir/ritonavir [14]. Viral load clearance also was used in many studies for SARS-CoV-2 showing a gradual decrease in tertiary patients $[15,16]$.

Zou et al. [16] reported that patients with a severe form of COVID-19 who required hospitalization in an intensive care unit had a high viral load 10 days after the onset of respiratory symptoms and later as well. Lescure et al. [17] reported the viral load dynamics of two patients who later developed respiratory deterioration despite the disappearance of nasopharyngeal viral RNA. They also suggested that the viral load could be used to indicate possible clinical strategies for the treatment of COVID-19.

We could not find any difference in viral load reduction among samples of patients considering the same time score established in other studies that analyzed the clearance of viral load in different clinical presentations. Liu et al. [18] in their study analyzed the clinical outcome of COVID-19 subjects but none patient was under HCQ.

The results of this study must be interpreted in light of methodological limitations. All patients included were hospitalized with moderate severity neither critical nor mild and the difference in viral load may be less striking than a large inclusion could demonstrate. In addition, it is possible that measuring viral load in the nasopharynx may not fully capture the total amount of virus shed by an individual. Patients were selected based on the availability of samples that had tested positive for COVID-19. Therefore, the sampling time of all serial samples for each patient presented some variation. To reduce any bias, we categorized all patients using the $\Delta \mathrm{Ct}$ and $\Delta t$ analysis to minimize that limitation.

In conclusion, we did not observe any change in viral load in vivo with the use of HCQ. Further studies with potential antiviral drugs should include virological analysis to evaluate in vivo impact of viral replication.

Acknowledgments L.K.S.L and J.M.A.C. are a fellow of the Coordenação de Aperfeiçoamento de Pessoal de Nível Superior (CAPES), Brazil. D.D.C. is a fellow of the Conselho Nacional de Desenvolvimento Científico e Tecnológico (CNPq), Brazil.

\section{References}

1. WHO(2020). Coronavirus disease 2019 (COVID-19), Situation Report - 51. World Health Organization

2. Gautret P, Lagier JC, Parola P, Hoang VT, Meddeb L, Sevestre J, Mailhe M, Doudier B, Aubry C, Amrane S, Seng P, Hocquart M,
Eldin C, Finance J, Vieira VE, Tissot-Dupont HT, Honoré S, Stein A, Million M, Colson P, la Scola B, Veit V, Jacquier A, Deharo JC, Drancourt M, Fournier PE, Rolain JM, Brouqui P, Raoult D (2020) Clinical and microbiological effect of a combination of hydroxychloroquine and azithromycin in 80 COVID-19 patients with at least a six-day follow up: a pilot observational study. Travel Med Infect Dis 34:101663

3. Luo P, Liu Y, Qiu L, Liu X, Liu D, Li J (2020) Tocilizumab treatment in COVID-19: a single center experience. J Med Virol 92:814-818

4. Xu X, Han M, Li T, Sun W, Wang D, Fu B, Zhou Y, Zheng X, Yang Y, Li X, Zhang X, Pan A, Wei H (2020) Effective treatment of severe COVID-19 patients with tocilizumab. Proc Natl Acad Sci U S A 117:10970-10975

5. Wang M, Cao R, Zhang L, Yang X, Liu J, Xu M, Shi Z, Hu Z, Zhong W, Xiao G (2020) Remdesivir and chloroquine effectively inhibit the recently emerged novel coronavirus (2019-nCoV) in vitro. Cell Res 30:269-271

6. Thachil J (2020) The versatile heparin in COVID-19. J Thromb Haemost 18:1020-1022

7. Savarino A, Di Trani L, Donatelli I, Cauda R, Cassone A (2006) New insights into the antiviral effects of chloroquine. Lancet Infect Dis 6:67-69

8. Yan Y, Zou Z, Sun Y, Li X, Xu KF, Wei Y, Jin N, Jiang C (2013) Anti-malaria drug chloroquine is highly effective in treating avian influenza A H5N1 virus infection in an animal model. Cell Res 23: 300-302

9. Andreani J, Le Bideau M, Duflot I, Jardot P, Rolland C, Boxberger $\mathrm{M}$ et al (2020) In vitro testing of combined hydroxychloroquine and azithromycin on SARS-CoV-2 shows synergistic effect. Microb Pathog 145:104228

10. Yao X, Ye F, Zhang M, Cui C, Huang B, Niu P, Liu X, Zhao L, Dong E, Song C, Zhan S, Lu R, Li H, Tan W, Liu D (2020) In vitro antiviral activity and projection of optimized dosing design of hydroxychloroquine for the treatment of severe acute respiratory syndrome coronavirus 2 (SARS-CoV-2). Clin Infect Dis 71:732739

11. Geleris J, Sun Y, Platt J, Zucker J, Baldwin M, Hripcsak G et al (2020) Observational study of hydroxychloroquine in hospitalized patients with Covid-19. N Engl J Med 382:2411-2418

12. Torjesen I (2020) Covid-19: Hydroxychloroquine does not benefit hospitalised patients, UK trial finds. BMJ: British Medical Journal (Online) 369:m2263

13. CDC. (2020) CDC 2019-Novel Coronavirus (2019-nCoV) Realtime RT-PCR diagnostic panel. Centers for Disease Control and Prevention

14. Lim J, Jeon S, Shin HY, Kim MJ, Seong YM, Lee WJ, Choe KW, Kang YM, Lee B, Park SJ (2020) Case of the index patient who caused tertiary transmission of COVID-19 infection in Korea: the application of lopinavir/ritonavir for the treatment of COVID-19 infected pneumonia monitored by quantitative RT-PCR. J Korean Med Sci 35:e79

15. Zheng S, Fan J, Yu F, Feng B, Lou B, Zou Q et al (2020) Viral load dynamics and disease severity in patients infected with SARSCoV-2 in Zhejiang province, China, January-March 2020: retrospective cohort study. BMJ. 369:m1443

16. Zou L, Ruan F, Huang M, Liang L, Huang H, Hong Z, Yu J, Kang M, Song Y, Xia J, Guo Q, Song T, He J, Yen HL, Peiris M, Wu J (2020) SARS-CoV-2 viral load in upper respiratory specimens of infected patients. N Engl J Med 382:1177-1179

17. Lescure FX, Bouadma L, Nguyen D, Parisey M, Wicky PH, Behillil S, Gaymard A, Bouscambert-Duchamp M, Donati F, le Hingrat Q, Enouf V, Houhou-Fidouh N, Valette M, Mailles A, Lucet JC, Mentre F, Duval X, Descamps D, Malvy D, Timsit JF, Lina B, van-der-Werf S, Yazdanpanah Y (2020) Clinical and 
virological data of the first cases of COVID-19 in Europe: a case series. Lancet Infect Dis 20:697-706

18. Liu Y, Yan LM, Wan L, Xiang TX, Le A, Liu JM et al (2020) Viral dynamics in mild and severe cases of COVID-19. Lancet Infect Dis $20: 656-657$
Publisher's note Springer Nature remains neutral with regard to jurisdictional claims in published maps and institutional affiliations. 